\title{
Optimal Management Helps Reducing Risks for Potable-Water Resources in Albania
}

\author{
Alba Robert Dumi \\ “Ismail Qemali” Vlore University, Vlore, Albania
}

\begin{abstract}
Albania is located on the eastern shore of the Adriatic and Jon Sea, south of former Yugoslavia, north of Greece, and west of Macedonia. It is divided into three agro-ecological zones based on climate, soils and vegetation: the fertile coastal plains, the intermediate hilly region, and the non-arable mountain zones. Annual rainfall varies from 800 to $2,000 \mathrm{~mm}$ in coastal areas to 1,600 to $2,000 \mathrm{~mm}$ in the hilly regions and up to $3,000 \mathrm{~mm}$ in the mountains. Rainfall is concentrated mainly in the winter, and less than 20 percent of annual rainfall occurs in the six-month period between April and September. Studies indicate that available sources of supply could provide more than enough to satisfy the country's overall water demand. In many cities, water availability at the source is about 500-700 litres per capita per day, but leaks and waste mean that only a small fraction of water produced is consumed. The paper research concludes that the Albanian government should: (1) Introduce and implement new anti-corruption laws to increase the market transparency; (2) Continue the ongoing institutional and economical reform to deliver better legal institutions and market efficiency; (3) Reduce anti-competitive practices such as government monopoly in some sectors and privatize all the strategic sectors; and (4) Urgently develop with the help of International Monetary Fund, new projects regarding infrastructure with clear the National Investment Promotion Agency from the bureaucratic procedures and further increase the budget to improve the whole internal infrastructure.
\end{abstract}

Keywords: municipalities, NGOs, Urban areas, drinking water, social leadership, strategic changes

\section{Introduction}

\section{Community Drinking Water Treatment for Emergencies and Remote Locations}

Almost everywhere problems of water scarcity can be considerably mitigated through metering, leakage detection and reduction, network improvements, disconnection of illegal connections, and optimization of storage and supply patterns. The distribution problem in Albania also has a seasonal aspect: much more water is needed during the summer growing season. When rainfall is scarce, rural drinking water is often misused for irrigation, and the tourist resort areas use large amounts of water. On average, water is available only 3-4 hours per day, with certain areas receiving water only once in three days.

Albania faces a water distribution problem, not a water production problem. The main issues handled out in this presentation are: strengthening local government leadership and initiative; partnership between

\footnotetext{
Alba Robert Dumi, Ph.D., Associate Professor, Director of Graduated level, Economy Faculty, Management Department, “Ismail Qemali” Vlore University.

Correspondence concerning this article should be addressed to Alba Robert Dumi, “Ismail Qemali” University, Sheshi Pavarsia, Skele Vlora, 1001 Vlorë, Albania. E-mail: besi.alba@yahoo.com.
} 
municipalities and NGOs; Fullani (2010) concluding all of these in the community-based approaches to infrastructure services and neighborhood revitalization. The earth's climate is changing and its atmosphere is warming. What might this mean for freshwater resources? The facts indicate the information like that:

- Rising water demands: Hotter summers mean thirstier people and plants. Temperature increases will likely contribute to higher water demands (Aessten, 2007). In addition, more evaporation from reservoirs and irrigated farmland will lead to faster depletion of water supplies;

- Scientific evidence suggests that rising temperatures in the south western United States will reduce river flows and contribute to an increased severity, frequency, and duration of droughts. Many utilities depend on winter snowpack to store water and then gradually release it through snowmelt during spring and summer. (Allen \& Wood, 2009).Almost everywhere problems of water scarcity can be considerably mitigated through metering, leakage detection and reduction, network improvements, disconnection of illegal connections, and optimization of storage and supply patterns (Bissederl \& Shorl, 2011);

- Warmer temperatures will accelerate snowmelt, causing the bulk of the run-off to occur earlier-before crops can use the water-and potentially increasing water storage needs in these areas; Identify advances in detection, monitoring and modeling, analytical methods, information needs and technologies, research and development opportunities, and communication strategies that will enable the water supply industry and other stakeholders to further reduce risks associated with public water supply distribution systems (Avolio \& Bass, 1985). Water quality problems and issues are both local and regional as evidenced by a variety of reports included in Hydro Management (1989, 2003, 2010).

\section{Albania and National Recourses}

Water capita for agricultural user in Albania is the most important sector, presently accounting for over $50 \%$ of GDP and employment (Mancellari, 2004). Due to the importance of this sector and the need for irrigation, the previous regime made massive investments in irrigation and drainage between 1950 and 1975. By the end of 1980s, about 420,000 ha of land, representing over 50\% of Albania's arable land and delivering some $80 \%$ of its agricultural production, was provided with irrigation facilities. Drainage was also recognized as a necessity along with the irrigation (Bech \& Soramki, 2008). A substantial part of irrigation development is in the coastal plains, where soils are heavy and the land is flat since much of it was reclaimed from swamps. As winter rain frequently causes water logging, extensive networks of drainage have also been developed: (1) Water resource: Albania is a water-rich country, with an annual average of 3,080 $\mathrm{m}^{3}$ per capita, the highest in Central and Eastern Europe (Guxolli \& Ruli, 2011). Total run-off equals on average 25.7 billion $\mathrm{m}^{3}$ per year, of which $2 \%$ or 588 million $\mathrm{m}^{3}$ can be stored in irrigation reservoirs. This water, together with 450 million $\mathrm{m}^{3}$ diverted from rivers and lakes, constitutes the present volume of 1.0 billion $\mathrm{m}^{3}$ available for irrigation from surface water; and (2) Irrigation and Drainage Infrastructure: system size and fragmentation. Irrigation systems are highly fragmented since $55 \%$ of the irrigation command area is supplied by small systems covering less than 5,000 ha (Bregu, 2009). Some 653 dams and reservoirs supply water to about 184,000 ha, and 639 pumping stations with some 1,250 electrical pumps and installed power of about 200,000 KW provide lift irrigation from rivers and lakes for about 78,000 ha. Run-of-river schemes account for water on some 160,000 ha, with groundwater supplying the remaining 1,000 ha of land under irrigation command.

\section{Water Quality and Urbanization in Albania}

EU (European Union) supplemented Albanian government with national programs and projects. 
Water quality assessments are in charge of the Department of Environmental Protection (PADEP), and testimony received by the committee. Some of these water quality problems are associated primarily with urbanization vicinity; some are associated with activity in the Allegheny River basins; still others are common to the predominantly rural counties. Large differences exist among the sources of problems, their potential effects on Albanian public health and environmental quality, and their likely solutions. Further, resolution of water quality issues is affected by other regional issues such as transportation, land use, and governance of the metropolitan area (Shulku \& Zoto, 2007).

We construct this paper research under two hypotheses like that:

H1: The Albanian reforms and Albanian progressing water system, aimed to create the managerial and professional nucleus required to lead any serious efforts to improve the accountability and performance of public institutions.

H2: Albania faces a water distribution problem, not a water production problem. Studies indicate that available sources of supply could provide more than enough to satisfy the country's overall water demand.

The European Union supplements these national programs with coordinated assistance aimed at promoting economic development, assisting distressed localities and fostering social inclusion. Infrastructure is an important component of these programs. In strong local government leadership and active community participation were keys to implementing an integrated plan involving urban planning, infrastructure, and economic development. Despite its location in an industrialized province Albanian's economy relies on wine production, which, in recent years has been declining (Albania: Municipal Water and Sanitation Project-Social Assessment. Washington, D.C., 2010). Weak community participation, inadequate infrastructure, poor accessibility to regional resources and an un-skilled labor force compounded the effects of massive job cuts in the wine industry. To address these problems, Albania launched a new strategy for economic recovery in 1990-1993, shifting the emphasis from seeking to attract investments from sources outside the municipality to fostering local integrated development (Irwin \& Homewood, 1985).

There are seven key factors for development the Albanian infrastructure:

- A dynamic local government leadership;

- A coherent strategy acted upon with determination;

- A healthy climate of cooperation with business;

- Local government's investment initiatives to jumpstart the stagnant economy;

- Creative use EU funds to implement local policy;

- Efficient municipal administration;

- Coherent links among urban planning, infrastructure and economic development.

\section{Methodology of Paper Research}

The research methodology used to complete this article is that to compare the latest international economic policies to respond to different features present or not in them (Ruli, 2004). The environment is significantly limited by the institutional framework that the rules of the game and is controlled by public administration and is responsive to the needs of foreign companies: (1) In the empirical part of the paper, the author analyzes selected indicators for responsiveness of the public administration in selected Albanian programs, compared EU. Review all Albanian reforming policies and adapt a new program to provide more competitive incentives than other countries; (2) Increase the number of skilled workforce through developing and modernizing the 
educational and vocational training; (3) Reform the whole judicial system, to gain the public opinion support; and (4) Build an efficient R\&D department for the country benefits and economic strategies (Albanian Local Government Support Program (CSLGP)).

Finally, this paper research aims to investigate, analyze and evaluate Albanian's current position and performance in attracting FDI. We can conclude that the Albanian market is very interesting for foreign investors, but based on the evidence found it is difficult to conclude that it is competitive in the Balkan market (Cynthia McCauley, 2009). In this context, the Albanian governments should be very serious in developing and implementing new strategies to help all the foreign companies to heavily invest in all strategic sectors. The assessed projects were prepared and implemented during a time of major political and economic changes in Albania. The projects successfully addressed urgent rehabilitation needs to ensure the continuity of the vital water supply and sewerage services with the main focus on the rehabilitation of the existing facilities. Performance was less successful on institutionalization although this improved under the Urgent Rehabilitation project (Gene Klan, 2009). Generally, institutional objectives were too optimistic compared timeframe to build a constituency and accomplish fundamental reforms.

\section{Partnerships Between Municipalities and NGOs}

Albania, one of the smallest and poorest countries in Eastern Europe, has experienced a transition marked by sharp economic swings and periods of civil strife. The early phases of decentralization witnessed the transfer of political autonomy and limited administrative and fiscal authority, to local governments, inadequate legislation outlining central/local responsibilities, scarce financial resources and deficient infrastructure strained the capacity of local governments to mange urban services (Ruli, 2011).

In January 2000, the government promulgated a national Strategy for Decentralization and Local Autonomy which includes laws to strengthen the autonomy of local governments and increase their capacity to manage local infrastructure and services. In the absence of fiscal resources to improve infrastructure in urban and rural areas, the government, with donor assistance, initiated community-driven development strategies to provide infrastructure services based on a cost sharing formula and to set up participatory management structures (Dumi, 2011).

In Tirana sustained population growth since 1991-1999 led to rapid expansion of the urbanized area, resulting in the proliferation of informal settlements. With an estimated population of 575,000 in 1997, 6,500 families were seeking new housing each year. Local government, even with central transfers, could accommodate only five percent of the demand for new infrastructure. Supported by donor assistance and international and local NGO's the city initiated a community-based development strategy in the informal settlement.

The program brought together local government teams, NGO's and residents to formulate a development plan for the neighbor define priorities for improvements and determine equitable cost-sharing formulas to finance infrastructure (Govern of Albania, Ministry of Economy, 2010, p. 6).

This partnership led to the upgrading of roads and electrical networks, the construction of community buildings and schools, improved public spaces and program for youth. Clarifying the legal status of residential land and formalizing an urban plan resulted in the sufficient leveraging of community and household resources to provide infrastructure and build new housing. In 1997, the experience was expanded to a citywide effort and was subsequently funded by the Word Bank. As the local government teams and NGO's gain experience and residents begin to trust the local government, Tirana Land management Program is scaling up and expanding to 
other formal and informal residential zones in Tirana.

Similar community-based initiatives were structured in rural areas. As part of an IDA funded Irrigation Rehabilitation Project, 250 Water uses Associations (WUAs) were created to manage irrigation and drainage systems. Finally, the engagement of senior government officials in the dissemination of project information secured commitment among communities and farmers.

However, the inability to generate local revenue has undermined the effectiveness of local government, it has adopted a "Two-Point Strategy", incorporated in the community infrastructure program: (1) To work closely with Community-Based organizations so as to enhance their capacity to participate in development programs and strengthen the City Council's capacity to respond to requests from communities; (2) To adopt a new approach to Environmental Planning and Management based on capacity building; (3) This is a highly significant feature of infrastructure programs and carries important implications for local development; and (4) The main objective was to build a new working relationship between residents and city officials, based on a shared vision of the future and "a lasting trust" (Hofer \& Schendel, 1983).

Because the districts were designated as urban renewal sites, residents in the older zones could not upgrade their infrastructure and households in the subserviced extensions could not connect to existing networks. Repairs to buildings are also prohibited, except in the case of roof leaks. This state of affairs lasted over 30 years resulting in resentment and distrust of municipal authorities (Ray Blunt, 2006).

\section{Community-Based Approaches to Infrastructure Services}

The act for support of local investment committed the municipality to cover 50 percent of the cost of water, sewerage and power lines, 70 percent of the cost of roadbeds and sidewalks and 100 percent of the cost of drainage and street paving. The cost sharing formula can be modulated to take into consideration issues of equity and cost burden. As an incentive to private rehabilitations of buildings, investors are granted a three year exemption from property taxes (Guxholli \& Karapici, 2011). During the years 1994-1999 in Albania, the partnership between the municipality and the residents was institutionalizes through the Local Initiatives Program to ensure its continuity as a citywide development strategy (Ministry of Economy, 2010).

\section{The Importance of Political Reforms in Albania and in Eastern Countries}

Decentralization has been at the heart of political reform, whether in Central and Eastern Europe after 1989, in the Balkans after the wars of the 1990s, or in Indonesia and Peru after the fall of Suharto and Fujimori (Irwin \& Homewood, 1985). It breaks up the monopoly of power, offers some local autonomy to ethnic minorities, and makes local services more accountable to their clients. The first results of the used strategy emerge from the current situation of the macroeconomics variables. Output growth was showing a persistent improvement compared to other countries in similar conditions budget deficit and inflation diminishing. Although still very high, unemployment was moving down even slowly together with a fast development of the private sector (Kajtaz, 2002). The environment is significantly limited by the institutional framework that the rules of the game and is controlled by public administration and is responsive to the needs of foreign companies. One of its major amendments includes a better regulation for unsolicited proposals and of public-private partnerships in Albanian conditions.

The key features of the program are:

- Introducing participatory planning and community-based development processes through neighborhood development committees and street representatives working in partnership with the city; 
- Creating an enabling environment for private investment;

- Empowering citizens to pursue their own self improvement;

- Promoting privatization of the housing a stock and fostering the development of micro-enterprises;

- Ensuring the sustainability of activities initiated;

- Promoting the reliability of successful initiatives.

This process allowed the canton to build consensus, prepare a development plan, allocate municipal funds equitably leverage additional resources and improve infrastructure and living conditions. The participatory municipal management, improve infrastructure and living conditions.

\section{Conclusions and Recommendations}

Administrative changes in Albanian public policies as an obstacle to the operating foreign investments, comparison of EU. This includes partnerships with community-based organizations, public and private colleges, universities, public school teachers, public health departments (Albania-Rural Water Supply and Sanitation Strategy, 2003). Additionally, more number of community leaders have been trained to deliver educational workshops; PSI has developed a robust workshop leader database, which permits remote access to (and entry of) service delivery information. This will be an important point of administrative changes in Albanian public policies as an obstacle to the operating foreign investments, comparison of EU (De Soto, 2003).

Another point of administrative changes in Albanian public policies as an obstacle to the operating foreign investments, comparison of EU are: (1) Comprehensive Watershed Assessment and Response Plan (CWARP) recommended and discussed in Studies and Centre of Economic CESS; Corporate culture and productivity (Schein, 1992), it is desirable to have some mechanism to facilitate continued oversight of regional progress (or lack thereof) toward clean water and its relationships to other regional goals and activities, and to help realize the benefits of cooperation; (2) To meet these daunting challenges, the canton democratized its planning and management procedures. This process allowed the canton to build consensus, prepare a development plan, allocate municipal funds equitably leverage additional resources and improve infrastructure and living conditions; and (3) The participatory municipal management, improve infrastructure and living conditions (Flynn \& Parters, 2003).

We recommended these conclusions: (1) Introducing participatory planning and community-based development processes through neighborhood development committees and street representatives working in partnership with the city; (2) Creating an enabling environment for private investment; and (3) Empowering citizens to pursue their own self improvement.

- Promoting privatization of the housing a stock and fostering the development of water micro-enterprises;

- Ensuring the sustainability of activities initiated and promoting the reliability of successful initiatives in optimal management in reducing risk of potable water (Infrastructure Rehabilitation Project, 2001).

Albanian government will be reality these points: A dynamic local government leadership, coherent strategy acted upon with determination, healthy climate of cooperation with business, local government's investment initiatives to jumpstart the stagnant economy, creative use EU funds to implement local policy, and efficient municipal administration.

\section{References}

Adrian, F. (2010). Albanian publisher by Albania international bank 2010, report, Euro zone and Albania. 
Allen, W., \& Wood, G. (2009). Defining and achieving financial strategy. JFS Journal, 2(2).

Anthony, R. N., \& Dearden, J. (1980). Management control systems (4th ed.). Irwin.

Avolio, B. J., \& Bass, B. (1985). Charisma and beyond, academy of management. San Diego.

Bech, M. L., \& Soramki, K. (2008). Global of trends value payments. EPR Journal, FRB.

Bissederl, \& Shorl. (2011). Albania and open economy. Knowledge Transfer Review, 207.

Blunt, R. (2006). Public sector consortium, report 2006. ICMA’s Magazine, 8, 15, 24. Public Private Partnerships in the Water Sector Economics.

Bregu, M. (2009). National Albanian official page, Ministry of Economy, year 2010, July 2006 column for GovLeaders.org.

Cynthia, McCauley. (2009). Methodology (p. 128). GovLeaders.org.

De Soto, H., \& Egamberdi. (2001). Center for economic and social studies (CESS). Albania: Municipal Water and Sanitation Project-Social Assessment. Government of Albania. 2001-2003. The National Strategy for Socio-Economic Development (NSSED).

Dumi, A. (2010). The scarcity of drinking water in Albania. International conference. Vlora case study and Albanian Regions.

Dumi, A., \& Gjini, V. (2011). Institutional economic aspect in Albania. Study in Economical Faculty, Tirana University.

Gene Klan Holkers, of the Center for Creative Leadership and innovation (pp. 12, 23, 28).

Guxholli, Z., \& Karapici, V. (2011). The Albanian economy potential. Economy and Transition Review, 5(69), 123.

Guxolli, Z., \& Ruli, G. (2011). Tirana international research, Economic International Conference. Nr. 4(68) 2011 Study in Economical Faculty, Tirana University.

Irwin, \& Homewood. (1985). Industrial performance analysis, 1987-1988. In Business Policy and Management in Potable Water-Capacity.

Kajtaz, A. (2002). Impact evaluation of first capacity infrastructure rehabilitation project. Development and Cooperation in Albania Potable Water, 4, 8.

Legisi, E., \& Zoto, N. (2007). Albanian loans and collateral. Study in Economical Faculty, Tirana University.

Lorange, P. S., Morton, M. F., \& Ghoshal, S. (1986). Water strategic control, West ST Paul, M.N..

Ruli, G. (2004). Project management unit, ministry of agriculture and food (p. 45). Impact Evaluation of Second Irrigation and Drainage Rehabilitation Project. April 2004. 